\title{
New Record of Philonthus liopterus (Coleoptera, Staphylinidae) in Korea
}

\author{
Young Bok Cho* \\ Natural History Museum, Hannam University, Daejeon 306-791, Korea
}

\begin{abstract}
Philonthus liopterus Sharp is reported for the first time in Korea. A habitus photo and illustration of the male genitalia of this species are provided.
\end{abstract}

Keywords: taxonomy, Staphylinidae, Philonthus, new record, Korea

\section{INTRODUCTION}

The genus Philonthus Stephens is a large group of the genera of subfamily Staphylininae with approximately 1,255 species worldwide (Herman, 2001) and characterized by the largest lateral macrosetal puncture of the pronotum separated from the lateral margin by little more than the width of the puncture. The apical maxillary palpomere is more or less fusiform, usually more than 1.3 times as long as the penultimate palpomere (Smetana, 1995).

Philonthus samples were collected from Gangwon Province by Mr. Tripotin and identified as Philonthus liopterus Sharp, which is new to Korea. Including this species, a total of 33 species have been recorded in Korean Philonthus fauna. The diagnosis, habitus photo and illustrations of male genitalia of this species are reported.

\section{SYSTEMATIC ACCOUNTS}

Order Coleoptera Linnaeus, 1758

Family Staphylinidae Latreile, 1802

Genus Philonthus Stephens, 1829

1*Philonthus liopterus Sharp, 1889 (Fig. 1)

Philonthus liopterus Sharp, 1889: 36; Schillhammer, 1999:

61; Herman, 2001: 2865; Smetana, 2004: 646.

Philonthus kryzhanovskii Tichomirova, 1972: 1973 (treated as synonym of $P$. liopterus by Schillhammer, 1999).

Philonthus kralianus Hromadka, 1987: 149 (treated as synonym of P. liopterus by Schillhammer, 1999).
Material examined. Korea: Gangwon Province: 1 ऽ , Pyeongchang-gun, Jinbu-myeon, Mt. Odaesan near Dongdaesa, Alt.

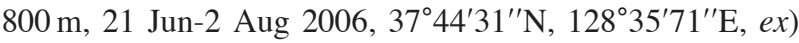
Malaise trap, P. Tripotin coll.; 1 우, Pyeongchang-gun, Yongpyeong-myeon, Nodong-ri, Nodong Valley, Alt. $900 \mathrm{~mm}$, 23 Jun-3 Aug 2006, 37 $42^{\prime} 08^{\prime \prime} \mathrm{N}, 128^{\circ} 28^{\prime} 89^{\prime \prime} \mathrm{E}$, ex) Malaise trap, P. Tripotin coll.

Diagnosis. Body length 8.3-9.0 mm, body black but elytra reddish black, strongly glossy, antennae and legs reddish brown. Head suborbiculate, eyes slightly prominent, antenomeres 6-10 wider than long. Pronotum subquadrate but slightly narrowing posteriorly, dorsal rows each with four punctures. Elytra piceous black and sparsely punctuate. Medain lobe of aedeagus very elongate and apical area very sharp, paramere short and apical area very sharp like needle; middle area trapezoidal and dense sensory peg setae present underside.

Distribution. Korea, Japan, Russia, and Tajikistan.

Remark. This species is identified easily from the other members of Korean Philonthus by strongly shining body and very sharp like needle of apex paramere.

\section{ACKNOWLEDGEMENTS}

The author wishes to thank Mr. Tripotin for the valuable rove beetles specimens. This study was supported by the project on survey and excavation of Korean indigenous species of the National Institute of Biological Resources (NIBR) under the Ministry of Environment, Korea.

\footnotetext{
(c) This is an Open Access article distributed under the terms of the Creative Commons Attribution Non-Commercial License (http://creativecommons.org/ licenses /by-nc/3.0/) which permits unrestricted non-commercial use, distribution, and reproduction in any medium, provided the original work is properly cited.
}

\section{*To whom correspondence should be addressed Tel: 82-42-629-7699, Fax: 82-42-629-8245 \\ E-mail: silpha@hanmail.net}

Korean name: ${ }^{1}$ *광택좀반날개 (신칭) 

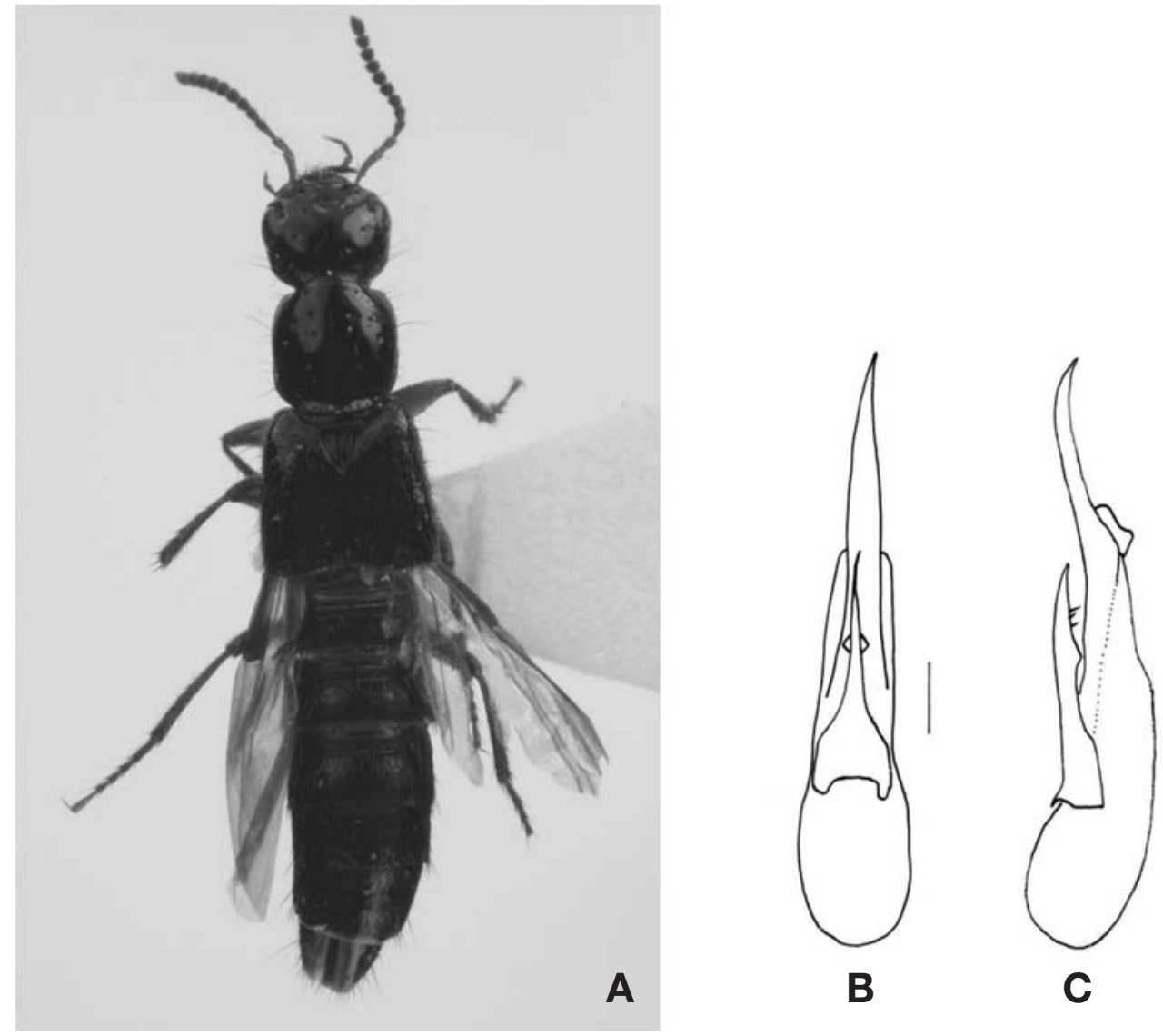

Fig. 1. Philonthus liopterus. A, Habitus, $8.9 \mathrm{~mm}$; B, Ventral view of aedeagus; C, Lateral view of aedeagus. Scale bar: $B, C=0.14 \mathrm{~mm}$.

\section{REFERENCES}

Herman LH, 2001. Catalog of the staphylinidae (Insecta: Coleoptera): 1758 to the end of the second millennium. V. Staphylinine group (part 2), Staphylininae: Diochini, Maorothini, Staphylinini, Othiini, Platyprosopini, Staphylinini (Amblopinina, Anisolinina, Hyptiomina, Philonthina). Bulletin of the American Museum of Natural History, 265:2441-3020.

Schillhammer H, 1999. Nomenclatoral and distributional notes on the subfamily Staphylininae (Coleoptera: Staphylinidae). Entomological Problems, 30:61-62.

Sharp D, 1889. The Staphylinidae of Japan. Annals and Magazine of Natural History, 6:28-44.

Smetana A, 1995. Rove beetles of the subtribe Philonthina of America north of Mexico (Coleoptera: Staphylinidae): classification, phylogeny and taxonomic revision. Memoirs on Entomology, International Vol. 3. Associated Publishers,
Gainesville, FL, pp. 1-946.

Smetana A, 2004. Family Saphylinidae: Omaliinae, Proteininae, Micropeplinae, Dasycerinae, Phleocharinae, Olisthaerinae, Tachyporinae, Trichophyinae, Habrocerinae, Aleocharinae, Trigonurinae, Apaticinae, Piestinae, Osoriinae, Oxytelinae, Oxyporinae, Megalopsiinae, Steninae, Euaesthetinae, Leptotyphlinae, Pseudopsinae, Paederinae, Staphyliniae. In: Catalogue of Palaearctic Coleoptera. Vol. 2: Hydrophiloidea Histeroidea Staphylinoidea (Eds., Löbl I, Smetana A). Apollo Books, Stenstrup, pp. 1-942.

Tichomirova AL, 1972. Staphylinidi (Coleoptera, Staphylinidae) Yuzhnovo promorya. In: Ekologiya pochvennykh bezpozvonochnykh (Ed., Gilyarov MS). Nauka, Moscow, pp. 144173 (in Russian). 